\title{
Production of Ferroalloys and Recycling in the Continuous Oxygen Reactor
}

\section{E.A. But, R.M. Mustafin, and A.V. Pavlov}

NUST «MISiS», Moscow, Russia

\section{Abstract}

A new technology for the production of ferronickel in a new type of unit - a continuous oxygen reactor (COR). The heat source of the process is heat from the afterburning of the exhaust gases. High recovery rate is achieved by carrying out the recovery process in the ore-coal briquettes. Briquettes are located on a carbon substrate. The products are metal and slag granules. The process is characterized by satisfactory performance and low cost of ferronickel.

Keywords: ferroalloy industry, continuous oxygen reactor, briquettes, ferronickel

Corresponding Author:

E.A. But

pav-gnts@misis.ru

Received: 5 February 2019

Accepted: 6 March 2019

Published: 17 March 2019

Publishing services provided by

Knowledge E

(c) E.A. But et al. This article is distributed under the terms of the Creative Commons

Attribution License, which permits unrestricted use and redistribution provided that the original author and source are credited.

Selection and Peer-review under the responsibility of the NIOKR-2018 Conference Committee.

\section{Introduction}

To date, there is a difficult situation in the ferroalloy industry in the world: the reserves of rich ores are running out, while environmental requirements and standards for the development of deposits are tightening, and the cost of electricity increases annually. All this, combined with a fall in the market price for metals and a sharp rise in the cost of electrodes, made it economically impractical to produce ferroalloys from poor ores using classical technologies. This led to a complete or partial shutdown of production at the leading ferroalloy enterprises of the Russian Federation.

Also, in the territory of the Russian Federation and the nearest countries a large amount of technogenic waste containing a large amount of valuable metals has been accumulated, which must be returned to production, thereby solving two tasks - returning expensive metals to production and solving environmental problems associated with the disposal of waste and the spread of harmful compounds from them into the environment.

In recent decades, single-stage processes of direct reduction of metals on the basis of an annular rotary kiln furnace (RHF technologies), such as ITmk3, Drylron, Inmetco, FASTMET, Redsmelt, have become increasingly popular. The ITmk3 technology, developed in 1996 by the Japanese company Kobe Steel LTD [1] and the oxygen reactor [2], using orecoal briquettes, which makes it possible to involve ores of small classes, dust and other 
metallurgical wastes in production, has gained the most popularity. Such technologies are more economical than classic production schemes. Therefore, the development and implementation of a single-stage solid-liquid-phase method for the production of ferroalloys from poor ores and waste products is a very urgent and promising task.

It was developed on the basis of the conducted research [3, 4] and was tested in industrial conditions a new scheme for an off-site method of processing ores and industrial wastes, tested for the production of ferronickel from poor oxidized nickel ore from the Buruktalsky mining sites and the processing of galvanic wastes to produce a commercial product.

The process of producing ferronickel from ore-nickel briquettes is carried out in the unit, hereinafter referred to as a continuous oxygen reactor (COR), which is a tunnel heating furnace (linear or ring) with a car bottom and consisting of the following zones (Figure 1):

1. the zone of formation on the tape of an aggregate of an impenetrable carbon packing (for example, from a mixture of coal and limestone) and laying on it a single layer of ore-nickel briquettes;

2. pre-heating zones of the charge to a temperature of $600-800^{\circ} \mathrm{C}$;

3. recovery zone with a maximum temperature of $1500^{\circ} \mathrm{C}$.

4. water cooling zone to a temperature of $300^{\circ} \mathrm{C}$, followed by unloading belt.

Rough-coal briquettes with a characteristic size of $30 \mathrm{~mm}$ (the standard size of an industrial briquette produced by a briquetting press) are continuously supplied to the first preheating zone. Due to the heat of gas-air (or gas-oxygen) burners, the briquettes and the top layer of the nozzle are heated to $600-800^{\circ} \mathrm{C}$. As a result, moisture is evaporated from the coal that makes up the briquettes and the carbon of the carbon packing, and volatile hydrocarbons are released. The released gases and the heated charge, together with the natural gas combustion products heated to $1000^{\circ} \mathrm{C}$, enter the second zone of the unit.

In the second recovery zone, as the temperature rises from $800^{\circ} \mathrm{C}$ to $1500^{\circ} \mathrm{C}$, reduction processes occur in the ore-coal briquettes, metal and slag phases appear, and melt drops form. Sources of heat from the process are heat from burning volatile substances coming from the first COR zone, and heat from the afterburning of carbon monoxide formed in the second zone during the direct reduction of carbon oxides by carbon with oxygen gas supplied to the second zone by oxygen lances. Oxygen tuyeres are installed in the walls of the unit with a step of $0.5-1 \mathrm{~m}$. 
In the water cooling zone, the ribbon is dusted with water to a temperature of 200$300^{\circ} \mathrm{C}$, followed by unloading the tape, and first a thin surface layer is removed from the tape, where recovery products are concentrated, and then, when the tape is turned, the calcined carbon cap is dropped from it.

The resulting metal and slag droplets are further separated using magnetic separation, and the spent carbon packing, consisting essentially of char and lime, is crushed to a fraction of less than $1 \mathrm{~mm}$, then it is used to make the original coal-briquette.

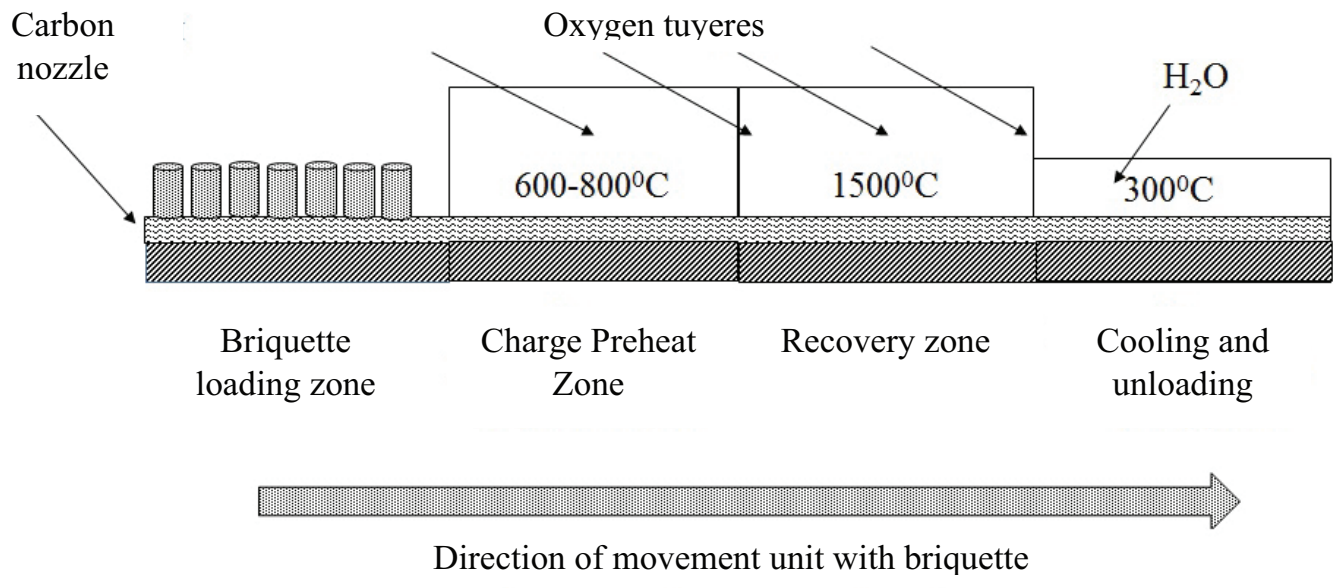

Figure 1: Scheme of a continuous oxygen reactor (COR).

The main advantages of the new technology are:

- minimal preparation of the charge (averaging, crushing, briquetting);

- obtaining two commercial products at the same time (metal and semi-coke);

- self-sufficiency of technology with its own heat;

- lack of lining;

- adaptive technology for any production capabilities (roll-hearth furnace, sintering belt and others);

- the possibility of processing almost any type of raw materials (ore of small classes, industrial wastes);

- low predicted cost price of a commercial product in comparison with classical technologies of production of ferroalloys.

Pilot tests were carried out for the production of ferronickel from oxidized nickel ore from the Buruktalsky deposit under conditions of a continuous oxygen reactor at CJSC Kamyshin Casting - Ferroalloy Plant (Volgograd Region, Kamyshin). 
The continuous oxygen reactor tested at the factory was modeled on an existing unit a car bottom furnace and had a melting space of $2.5 * 5 * 5 \mathrm{~m}$. The reactor was equipped with six oxygen tuyeres. The total consumption of oxygen through all tuyeres was $80 \mathrm{m3}$.

Three test melts were carried out. The total duration of melting from briquette loading to unloading was 40 minutes. The visual assessment of the surface temperature of the carbon packing was $1300-1400^{\circ} \mathrm{C}$. The recommended temperature $T=1500^{\circ} \mathrm{C}$ of the process was not reached, due to the lack of technological ability to raise the process temperature to the required one.

Experienced briquettes partially melted, but complete separation due to insufficiently high temperature into separate slag and metal phases did not occur. The briquettes were made thin sections and analyzed on an electron scanning microscope ("Quanta 650 SEM FEl", equipped with X-ray microanalysis system). The results of the analysis showed that nickel was completely reduced, there was not enough temperature to completely melt the briquette and form a single metal granule.

The tests confirmed the profitability and high technical and economic indicators of the process: at a total cost of $6.5-7.0 \$ / \mathrm{kg}$ of nickel at a market value of $9-10 \$ / \mathrm{kg}$ of nickel.

\section{References}

[1] Patent No. 2313595 (Japan). The method of obtaining ferronickel and the method of obtaining starting material for the production of ferronickel/Tanaka Hidetosi (JP), Harada Takao (JP), Sugitatsu Hiroshi (JP), Miyyara Ituo (JP), Kobayashi Isao (JP).//Patentee KABUSIKI KAYSYA KOBE SEIKO SE (JP).

[2] Patent number 2109817 of the Russian Federation. The method of producing iron and ferroalloys/Grigoryan V.A., Pavlov A.V., Wegman E.F., Semin A.E., Shcherbakov V.A.//Patentee MISiS. - The priority of the invention 16.10.97.

[3] But E.A., Pavlov A.V. Study of solid-liquid carbothermic reduction of nickel from orecoal briquettes//News of High schools. Ferrous Metallurgy, 2018. - No. 61 (2). - p. 120 $-127$.

[4] But E.A., Pavlov A.V., Mustafin R.M. Carbothermal solid-liquid reduction of nickel of oxidized nickel ore from ore-coal briquettes//Steel, 2018. - No. 4. - P. 18 - 20. 